\title{
Extrusion of Contracaecum osculatum nematode larvae from liver of cod (Gadus morhua)
}

\author{
S. Zuo $\cdot$ L. Barlaup $\cdot$ A. Mohammadkarami $\cdot$ A. Al-Jubury $\cdot$ D. Chen $\cdot$ P.W. Kania $\cdot$ K. Buchmann
}

\begin{abstract}
Baltic cod livers have during recent years been found increasingly and heavily infected with third stage larvae of Contracaecum osculatum. The infections are associated with an increasing population of grey seals which are final hosts for the parasite. Heavy worm burdens challenge utilization and safety of the fish liver products and technological solutions for removal of worms are highly needed. We investigated the attachment of the worm larvae in liver tissue by use of histochemical techniques and found that the cod host encapsulates the worm larva in layers of host cells (macrophages, fibroblasts) supported by enclosures of collagen and calcium. A series of incubation techniques, applying compounds targeting molecules in the capsule, were then tested for their effect to induce worm escape/release reactions. Full digestion solutions comprising pepsin, $\mathrm{NaCl}, \mathrm{HCl}$ and water induced a fast escape of more than $60 \%$ of the worm larvae within 20 min and gave full release within $65 \mathrm{~min}$ but the liver tissue became highly dispersed. $\mathrm{HCl}$ alone, in concentrations of 48 and $72 \mathrm{mM}$, triggered a corresponding release of worm larvae with minor effect on liver integrity. A lower $\mathrm{HCl}$ concentration of $24 \mathrm{mM}$ resulted in $80 \%$ release within 35 min. Water and physiological saline had no effect on worm release and $1 \%$ pepsin in water elicited merely a weak escape reaction. Besides the direct effect of acid on worm behavior it is hypothesized that the acid effect on calcium carbonate in the encapsulation, with subsequent release of reaction products, may contribute to activation of $C$. osculatum larvae and induce escape reactions. Short term pretreatment of infected cod liver, and possibly other infected fish products, using low acid concentrations is suggested as part of a technological solution for worm clearance as low acid concentrations had limited macroscopic effect on liver integrity within $35 \mathrm{~min}$.
\end{abstract}

Keywords Cod $\cdot$ Nematode $\cdot$ Liver $\cdot$ Worm clearance

Corresponding author: Kurt Buchmann, e-mail: kub@sund.ku.dk

Laboratory of Aquatic Pathobiology, Department of Health and Animal Sciences, Faculty of Health and Medical Sciences, University of Copenhagen, Frederiksberg C., Denmark 


\section{Introduction}

The nematode Contracaecum osculatum (Rudolphi, 1802) occurs as adult in pinnipeds and as third stage larva in crustaceans and fish (Køie and Fagerholm 1995; Zuo et al. 2016; Nadolna-Altyn 2017). It belongs to the family anisakidae, and may, as various species within the genera Anisakis and Pseudoterranova, be associated with the human zoonotic disease anisakidosis. Thus, several human cases of larval invasion of the gastro-intestinal tract, due to ingestion of under-cooked fish products, have been reported (Schaum and Müller 1967; Shamsi and Butcher 2011; Nagasawa 2012) and animal experimentation using pigs has shown that $C$. osculatum larvae are able penetrate the host stomach mucosa and elicit eosinophilic granuloma formation (Strøm et al. 2015) corresponding to pathological reactions associated with Anisakis and Pseudoterranova infections (Bier et al. 1976). Early investigations during the 1980s reported merely weak infections of Baltic cod (Gadus morhua) (Haarder et al. 2014; Eero et al. 2015) but during recent years Baltic cod livers have been reported to be increasingly heavily parasitized (100\% prevalence, mean intensities below 90 parasites per fish but maximum intensities up to 370) by third-stage larvae of $C$. osculatum (Haarder et al. 2014; Mehrdana et al. 2014; Nadolna and Podolska 2014; Buchmann and Mehrdana 2016; Horbowy et al. 2016; Zuo et al. 2017). Cod in other marine areas in the Atlantic including Canadian, Icelandic and Celtic seas may be infected but at a considerably lower level (Boily and Marcogliese 1995; Perdiguero-Alonso et al. 2008; Gay et al. 2017). Increased worm burdens in the Baltic Sea are caused by elevated infection pressures due to the increasing abundance of the final host, the grey seal Halichoerus grypus (Zuo et al. 2017) which are known to carry significant stomach infections of adult C. osculatum (Lunneryd et al. 2015; Zuo et al. 2017). Baltic cod liver contains dioxin and PCB which may interfere with marketing of the product (Godliauskiene et al. 2012) but the high rate of cod liver infections add to food hygienic concerns. Thus, nematode infections of fish products affect the safety and suitability of products for human consumption 
(Buchmann and Mehrdana 2016) and therefore methods to remove worms from the livers may increase safe exploitation of cod liver and possibly fish products in general. The present study using histochemical techniques describes partly the nature of the encapsulation material around the nematode larva in the cod liver. Based on these findings we subsequently evaluated a series of incubation methods, targeting specific components of the encapsulation, for extrusion of larval $C$. osculatum nematodes from Baltic cod livers. The concept is based on earlier observations on escape reactions of these third stage larvae when exposed to artificial digestion fluids (water, pepsin, $\mathrm{HCl}$, $\mathrm{NaCl}$ ), a method applied for enumeration of worms in Baltic cod liver (Mehrdana et al. 2014). The integrity of the livers during the incubation was evaluated to establish a possible exploitation for food processing.

\section{Materials and methods}

Fish

Cod (Gadus morhua) with total body lengths $35-48 \mathrm{~cm}$ were caught in the Baltic Sea immediately east of the island Bornholm (ICES SD 25) by a local fisherman. Livers (weight 19.4 to $34.8 \mathrm{~g}$ ) were removed on board the vessel immediately after catch, placed in plastic bags on ice and transported to the laboratory for processing within $18 \mathrm{~h}$ post-capture. For the extrusion study a total of $36 \mathrm{cod}$ were used and the entire liver from one fish was incubated in a beaker as described below.

\section{Fixation and sectioning for histology}

A subsample of other cod livers recovered were used for histology. Pieces of liver (from four cod specimens) with encapsulated nematode larvae were fixed in neutral ( $\mathrm{pH} 7.4) 4 \%$ formalin in PBS

(Hounisen, Denmark) for 24 hours, and then transferred to $70 \%$ of EtOH (Kemetyl, Denmark) until further processing including paraffin embedding, sectioning $(4 \mu \mathrm{m})$ and staining.

\section{Staining}


Tissue sections were stained by standard staining techniques including haematoxylin and eosin. Tissue calcium deposition was detected by applying the Alizarin red technique and tissue collagen deposition was visualized by use of van Giesson staining (Kiernan 1990).

\section{Identification of nematode larvae}

Nematode larvae were removed from liver tissue by pepsin/ $\mathrm{HCl}$ digestion, see below), conserved in ethanol and identified by light microscopy and PCR with subsequent sequencing of ITS. In brief, anterior and posterior parts of nematode larvae recovered from cod liver were placed in $70 \% \mathrm{EtOH}$ and transferred to Amann lactophenol (RAL Diagnostics, France) overnight for clearing. The worm parts were then mounted on microscope slides using mounting media Aquatex® (Merck, Germany) and identified according to Fagerholm (1982). For molecular identification the middle section of the worm conserved in $70 \%$ EtOH (Kemetyl, Denmark) was used for diagnosis based on PCR and subsequent sequencing performed according to Zuo et al. (2017). Two primers (forward primer (primer NC2) and reverse primer (primer NC5) (Zhu et al. 2007) were used.

\section{Extrusion solutions.}

Seven incubation solutions were tested for their effect to induce worm release from livers at $37{ }^{\circ} \mathrm{C}$. Media used included a full digestion solution consisting of physiological saltwater with pepsin (Orthana, Denmark) and hydrochloric acid. We compared the effect of this medium with pure water, physiological saline $(0.9 \% \mathrm{NaCl})$, pepsin in water $(1 \%)$, and hydrochloric acid in three concentrations (Table 1).

Incubation. A total of 36 glass beakers (each with a total volume 2 L) were divided into 7 groups (each consisting of $3-6$ beakers) for each treatment. A total of 36 cod livers (weight 19.4 to $34.8 \mathrm{~g}$ ) were placed individually in beakers whereafter the experimental solution was added (10 $\mathrm{ml}$ per $\mathrm{g}$ liver) whereafter incubation was conducted at $37^{\circ} \mathrm{C}$ under stirring $(300 \mathrm{rpm})$. Worms which left the liver tissue were isolated by pouring the solution through a sieve (mesh size 300 microns) at each 
time point $(5,20,35,50,65 \mathrm{~min})$ where after the fluid was poured back into the beaker with remaining liver tissue. The worm larvae were counted at each time point using a dissection microscope (magnification 7-40 X). In order to establish the total number of worms in the individual livers at the start of the experiment any worms remaining in the liver tissue after incubation (140 min) were recorded by the compression technique (Buchmann 2007). In brief, remaining liver tissue was compressed between two $10 \mathrm{~mm}$ glass plates (dimensions 150x150 mm) and scrutinized under the dissection microscope (10-40 x magnification) for counting of remaining worms.

\section{Evaluation of liver integrity.}

The liver tissue was subjected to gross macroscopical integrity assessment after 5, 20, 35, 50 and 65 min. Livers were characterized and ranked as 1) Intact, coherent, firm, 2) Slightly disintegrated surface, soft, 3) Partly disintegrated, fragmented, soft, 4) Highly disintegrated, very soft

\section{Statistics}

Release rates of different treatment groups from 0 to 65 min were analyzed by the Kaplan- Meier Plot (Graph Pad Prism 4.0) and differences between incubation groups were evaluated by the logrank (Mantel-cox) test with a probability level of 0.001 .

\section{Results}

Worm larvae isolated from Baltic cod livers were all diagnosed as $C$. osculatum sensu stricto both by morphometric (Fagerholm 1982) and molecular methods showing $100 \%$ similarity to GenBank No. JX467659 to JX467663 corresponding to findings by Haarder et al. (2014) and Mehrdana et al. (2014). Cod livers were all found infected with third stage larvae of C. osculatum (100\% infection) with intensities ranging between 9 and 91 parasites per liver (Table 1). 
Histology and histochemistry: Third stage larvae of C. osculatum were all found encapsulated in cod livers. The material surrounding the individual worm larvae consisted of outer concentric layers ( 2 to 4 cell layers) of macrophages and fibroblast-like cells enclosing inner amorphous layers showing positive reactions for collagen (Fig. 1a) and calcium (Fig. 1b). The hepatocytes distributed throughout the liver, and not directly associated with the encapsulation, were depleted of their lipid content due to histological processing (dehydration with ethanol and xylene) and appeared partly lysed.

Worm release: Worm counts in the individual livers were recorded and the percentages of escaped worms (in relation to the total number of worms in the liver before incubation) at the different time points were calculated for each treatment. The replicate groups within each incubation type did not differ significantly and the group data were pooled for comparison. The different treatments elicited significantly different escape reactions of the worms (Fig. 2, Table 2). Water alone and saltwater alone (showing no effect) and pepsin in water (showing slight effect) were the least effective media for induction of liver worm escape whereas full digestion solution $(\mathrm{HCl}, \mathrm{NaCl}$, water, pepsin) and $\mathrm{HCl}$ in the two highest concentrations (48 and $72 \mathrm{mM}$ ) elicited fast and statistically significant exit of the majority of nematode larvae within $20 \mathrm{~min}$ (Table 2). The lowest concentration of $\mathrm{HCl}(24$ $\mathrm{mM}$ ) showed a delayed release at $20 \mathrm{~min}$ but after $35 \mathrm{~min}$ no difference to higher concentrations were seen.

\section{Liver integrity}

Incubation of cod liver in water and saline alone did merely affect tissue integrity slightly as all livers could be ranked as 1) to 2) after 35 and $60 \mathrm{~min}$, respectively. Livers incubated in the $24 \mathrm{mM}$ $\mathrm{HCl}$ were ranked 2 at both time points. The two highest concentrations of $\mathrm{HCl}$ left livers characterized as 2) to 3). Liver tissue incubated in pepsin alone in water disintegrated partly (rank 
3). Full digestion medium left the livers clearly affected at 35 min (rank 3) and highly disintegrated in numerous tissue fragments (rank 4) at $65 \mathrm{~min}$.

\section{Discussion}

The present study showed that third stage larvae of $C$. osculatum actively leave livers from Baltic cod when exposed to various solutions of compounds which occur in the stomach fluids of the final host, the grey seal. Thus, full digestion solution composed of pepsin, $\mathrm{NaCl}$ and $\mathrm{HCl}$ induces a fast exit of a large part of the worms. Already after 5 min more than $50 \%$ of worms were cleared in this medium. However, it was found that $\mathrm{HCl}$ alone allowed release of nematode larvae from the liver tissues to a comparable level. This suggests that pretreatment of livers with relatively low concentrations of acid may be part of a technological solution for removal of C. osculatum larvae from fish tissue before processing for human consumption. We showed that the larvae were encapsulated in the liver tissue of cod by a marked cellular host reaction comprising macrophage and fibroblast-like cells with deposition of collagen and calcium in compartments around the parasite. Cellular encapsulation (comprising macrophages, mast cells and fibroblasts) of nematode larvae in fish tissue is a common reaction of the fish host towards larger pathogens which are not easily killed and eliminated by phagocytosis (Buchmann 2012) and similar reactions were recently described from livers of Gymnotus inaequilabiatus heavily infected with the nematode Brevimulticaecum and from the intestinal wall of Anguilla anguilla infected with Contracaecum rudolphii larvae (Dezfuli et al. $2016 \mathrm{a}, \mathrm{b}$ ). The worm larva is sequestered and relatively inactive in the host tissues but still able to survive the reaction for extended periods despite the reactions which may be due to release of immune regulating E/S products. Corresponding compounds from Anisakis simplex have been reported to regulate expression of inflammatory genes in rainbow trout (Bahlool et al. 2013) and recently Mehrdana et al. (2017) showed that C. osculatum E/S products limit expression of inflammatory genes in zebrafish. Following ingestion by the final host, the seal, the 
worm retain activity and will subsequently infect the stomach mucosa. The seal stomach environment contains the proteolytic enzyme pepsin (which may target collagen) and $\mathrm{HCl}$ which secures an appropriate low $\mathrm{pH}$ around 2 favouring pepsin activity. The acid itself was in this study shown to induce activation and worm escape from the ingested liver and that suggests that pepsin is not a crucial component to activate worms for their first escape reaction. The exact stimulus sensed by the worm and leading to escape is not known but it may be hypothesized that 1) acid has a direct effect on the worm, 2) interactions between acid and calcium carbonate may lead to release of free molecules (e.g. $\mathrm{CO}_{2}$ and $\mathrm{Ca}^{++}$ions) which may trigger worm activity. Degradation of collagen will release peptide fragments or free amino acids which may be sensed by the worm but this step does not seem to be crucial for activation and escape from liver. Similarly, the high body temperature $\left(37^{\circ} \mathrm{C}\right)$ alone was not the triggering factor as water and saline at this temperature had no effect. Occurrence of zoonotic nematode larvae in fish products is considered an increasing problem in various stocks of wild fish species and pretreatment of products with freezing or heat is needed to kill larvae and prevent infection of consumers (Chai et al. 2005). The anisakid nematodes in fish tissue release allergens which may cause problems in sensitized consumers (Lin et al. 2014, Mehrdana \& Buchmann 2017) and therefore removal of worms could be one way to reduce allergen contents and thereby increase food safety. However, it cannot be excluded that allergens diffuse into the liver tissue from the encapsulated worm and the high temperature $(37 \mathrm{C})$ used for incubation is known to increase the release of excretory/secretory compounds from anisakid nematode larvae (Bahlool et al. 2013). Therefore future studies must elucidate to which extent allergens remain in the product following worm removal by this method. These findings may indicate that pretreatment of cod livers with a $\mathrm{HCl}$ solution may be used for development of a technological solution for removal of worm larvae which may be used to increase the exploitation of this food resource from the Baltic. This nematode species is related to other genera, such as Anisakis and Pseudoterranova, 
all belonging to the family anisakidae. These parasites possess life cycles with inclusion of marine mammals as final host and invertebrates and fish as transport hosts (Mattiucci et al. 1998). This suggests that the presented methodology may be used to induce exit of worm larvae from other types of fish products infected by other worm types as well. For a technological worm removal solution it can therefore be recommended to explore the acid stimulation further. In this context it is noted that even low concentration of $\mathrm{HCl}$ had some macroscopic effect on liver integrity and therefore it is recommended to investigate if this treatment affect the organoleptic character and microstructure of the product which may interfere with industrial processing and quality of the fish products.

\section{Acknowledgements}

The present study was supported by the European Union's Horizon 2020 research and innovation programme through the grant agreement No. 634429 (Parafishcontrol)

\section{Conflict of interests}

The authors declare that they have no conflict of interests

\section{References}

Bahlool QM, Skovgaard A, Kania PW, Buchmann K (2013) Effects of excretory/secretory products from Anisakis simplex (Nematoda) on immune gene expression in rainbow trout (Oncorhynchus mykiss). Fish \& Shellfish Immunol 35:734-739

Bier JW, Jackson GJ, Earl FL, Knollenberg WG (1976) Gross and microscopic pathology with larval Anisakis sp. and Phocanema sp. nematodes from fish. Trans Am Microscop Soc 95:264-265

Boily F, Marcogliese D (1995) Geographical variations in abundance of larval anasakine nematodes in Atlantic cod (Gadus morhua) and American plaice (Hippoglossoides platessoides) from the gulf of St. Lawrence. Can J Fish Aquat Sci 52: 105-115

Buchmann K (2007) An introduction to fish parasitological methods - Classical and molecular techniques. Biofolia Publishers, Frederiksberg, Denmark p. 11-130

Buchmann K (2012) Fish immune responses against endoparasitic nematodes - experimental models. J Fish Dis 35: 623-635 
Buchmann K, Mehrdana F (2016) Effects of anisakid nematodes Anisakis simplex (s.1.), Pseudoterranova decipiens (s.l.) and Contracaecum osculatum (s.1.) on fish and consumer health. Food Waterb Parasitol 4: 13-22

Chai YL, Murrell KD, Lymberry AJ, (2005) Fish-borne parasitic zoonoses: status and issues. Int J Parasitol 35: 1233-1254

Dezfuli BS, Fernandes CE, Galindo GM, Castaldelli G, Manera M, DePasquale JA., Lorenzoni M, Bertin S, Giari L (2016a) Nematode infection in liver of the fish Gymnotus inaequilabiatus (Gymnotiformes: Gymnotidae) from the Pantanal region in Brazil: pathobiology and inflammatory response. Parasites \& Vectors 9 (473): 10.1186/s13071-016-1772-2

Dezfuli BS, Manera M, Bosi G, DePasquale JA, D’Amelio S, Castaldelli G, Giari L (2016b) Anguilla anguilla intestinal immune response to natural infection with Contracaecum rudolphii A larvae. J Fish Dis 39: 11-87-1200

Eero M, Hjelm J, Behrens J, Buchmann K, Cardinale M, Casini M, Kirkegaard E, Horbowy J (2015)

Eastern Baltic cod in distress: biological changes and challenges for stock assessment. ICES J Mar Sci 72(8): 2180-2186

Fagerholm HP (1982) Parasites of fish in Finland. VI Nematodes. Acta Acad Aboens 40 (6): 5-128

Gay M, Bao M, MacKenzie K, Pascual S, Buchmann K, Bourgau O, Couvreur C, Mattiucci S, Paoletti M, Hastie LC, Levsen A, Pierce GJ (2017) Infection levels and species diversity of ascaridoid nematodes in Atlantic cod, Gadus morhua, are correlated with geographic area and fish size. Fisheries Res (in press) http://dx.doi.org/10.1016/j.fishres.2017.06.006

Godliauskienė R, Petraitis J, Jarmalaitė I, Naujalis E (2012) Analysis of dioxins, furans and DLPCBs in food and feed samples from Lithuania and estimation of human intake. Food ChemToxicol 50(11): 4169-4174

Haarder S, Kania P, Galatius A, Buchmann K (2014) Increased Contracaecum osculatum infection in Baltic cod (Gadus morhua) livers (1982-2012) associated with increasing grey seal (Halichoerus grypus) populations. J Wildl Dis 50:537-543

Horbowy J, Podolska M, Nadolna-Altyn K (2016) Increasing occurrence of anisakid nematodes in the liver cod (Gadus morhua) from the Baltic Sea: Does infection affect the condition and mortality of fish? Fish Res 179: 98-103

Kiernan JA (1990) “Histological \& Histochemical Methods: Theory \& Practice.” 2nd ed. Oxford, UK: Pergamon Press Ltd.

Køie M, Fagerholm HP (1995) The life cycle of Contracaecum osculatum (Rudolphi, 1802) sensu stricto (Nematoda, Ascaridoidea, Anisakidae) in view of experimental infections. Parasitol Res 81: 481-489 
Lin AH, Nepstad I, Floorvaag E, Egaas E, Van Do, T (2014) An extended study of seroprevalence of anti-Anisakis simplex IgE antibodies in Norwegian blood donors. Scand J Immunol 79: 61-67

Lunneryd SG, Bostrom MK, Aspholm PE (2015) Sealworm (Pseudoterranova decipiens) infection in grey seals (Halichoerus grypus), cod (Gadus morhua) and shorthorn sculpin (Myoxocephalus scorpius) in the Baltic Sea. Parasitol Res 114: 257-64

Mattiucci S, Paggi L, Nascetti G, Ishikura H, Kikuchi K, Sato N, Cianchi R, Bullini L (1998)

Allozyme and morphological identification of shape: Anisakis, Contracaecum and Pseudoterranova from Japanese waters (Nematoda, Ascaridoidea). Syst Parasitol 40 (2): 81-92

Mehrdana F, Buchmann K (2017) Excretory/secretory products of anisakid nematodes: biological and pathological roles. Acta Vet Scand 59(42): 1-12

Mehrdana F, Bahlool QZM, Skov J, Marana MH, Sindberg D, Mundeling M, Overgaard BC, Korbut R, Strøm SB, Kania PW, Buchmann K (2014) Occurrence of zoonotic nematodes Pseudoterranova decipiens, Contracaecum osculatum and Anisakis simplex in cod (Gadus morhua) from the Baltic Sea. Vet Parasitol 205:581-587

Mehrdana F, Kania PW, Buchmann K (2017) Immunomodulatory effects of excretory/secretory compounds from Contracaecum osculatum larvae in a zebrafish inflammation model. PLOS One (accepted)

Nadolna K, Podolska M (2014) Anisakid larvae in the liver of cod (Gadus morhua L.) from the Southern Baltic Sea. J Helminthol 88:237-246

Nadolna-Altyn K., Podolska M., Szostakowska B. (2017) Great sandeel (Hyperoplus lanceolatus) as a putative transmitter of parasite Contracaecum osculatum (Nematoda: Anisakidae). Parasitol Res 116: 1931-1936

Nagasawa K (2012) The biology of Contracaecum osculatum sensu lato and C. osculatum A (Nematoda: Anisakidae) in Japanese waters: a review. Biosphere Science 51: 61-69

Perdiguero-Alonso D, Montero F, Raga JA, Kostadinova A (2008) Composition and structure of the parasite faunas of cod, Gadus morhua L. (Teleostei: Gadidae) in the North East Atlantic. Parasites \& Vectors 1: 1-18

Shamsi S, Butcher AR (2011) First report of human anisakidosis in Australia. Med J Austral $194: 199-200$

Schaum E, Müller W (1967) Die heterocheilidiasis. Eine Infektion des mensches mit Larven von Fisch Ascariden Dtsch Med Wochenschr 92:2230-2233 (in German)

Strøm SB, Haarder S, Korbut R, Mejer H, Thamsborg SM, Kania PW, Buchmann K (2015) Thirdstage nematode larvae of Contracaecum osculatum from Baltic cod (Gadus morhua) elicit 
eosinophilic granulomatous reactions when penetrating the stomach mucosa of pigs. Parasitol Res 114: $1217-1220$

Zhu XQ (2007) Identification of anisakid nematodes with zoonotic potential from Europe and China by single-strand conformation polymorphism analysis of nuclear ribosomal DNA. Parasitol Res 101(6):1703-7

Zuo S, Huwer B, Bahlool Q, Al-Jubury A, Christensen ND, Korbut R, Kania P, Buchmann K (2016) Host size dependent anisakid infection in Baltic cod Gadus morhua associated with differential food preferences. Dis Aquat Org 120:69-75

Zuo S, Kania PW, Mehrdana F, Marana MH, Buchmann K (2017) Contracaecum osculatum and other anisakid nematodes in grey seals and cod in the Baltic sea: molecular and ecological links. J Helminthol 26:1-9 doi:10.1017/S0022149X17000025 
Table 1. Composition of extrusion solutions and the mean number of $C$. osculatum third stage larvae in livers incubated. SEM: standard error of mean

\begin{tabular}{|c|c|c|c|c|c|c|c|}
\hline & $\mathrm{HCl}(\mathrm{ml})$ & $\mathrm{NaCl}(\mathrm{g})$ & Pepsin(g) & Water(ml) & $\begin{array}{l}\text { No. of } \\
\text { livers } \\
\text { incubated }\end{array}$ & $\begin{array}{l}\text { Mean } \\
\text { no. of } \\
\text { worms } \\
\text { per } \\
\text { liver }\end{array}$ & $\begin{array}{l}\text { SEM } \\
\text { (range) }\end{array}$ \\
\hline $\begin{array}{c}\text { Water } \\
\text { solution }\end{array}$ & 0 & 0 & 0 & 1000 & 6 & 28.3 & $\begin{array}{c}2.9 \\
(20- \\
42)\end{array}$ \\
\hline $\begin{array}{c}\text { NaCl, } \\
0.9 \%\end{array}$ & 0 & 9 & 0 & 1000 & 6 & 45.8 & $\begin{array}{c}4.2 \\
(16- \\
78)\end{array}$ \\
\hline $\begin{array}{c}\text { Digestion } \\
\text { solution }\end{array}$ & 6 & 9 & 10 & 1000 & 6 & 47.0 & $\begin{array}{c}5.7 \\
(31- \\
75)\end{array}$ \\
\hline $\begin{array}{c}\text { Pepsin, 1\% } \\
\text { (1) }\end{array}$ & 0 & 0 & 10 & 1000 & 6 & 52.8 & $\begin{array}{c}11.1 \\
(18- \\
91)\end{array}$ \\
\hline $\begin{array}{c}\mathrm{HCl} 24 \\
\mathrm{mM}\end{array}$ & 2 & 0 & 0 & 1000 & 3 & 26.0 & $\begin{array}{c}4.2 \\
(23- \\
41)\end{array}$ \\
\hline $\begin{array}{c}\mathrm{HCl} 48 \\
\mathrm{mM}\end{array}$ & 4 & 0 & 0 & 1000 & 3 & 26.0 & $\begin{array}{c}6.1 \\
(9-38)\end{array}$ \\
\hline $\begin{array}{c}\mathrm{HCl} 72 \\
\mathrm{mM}\end{array}$ & 6 & 0 & 0 & 1000 & 6 & 28.8 & $\begin{array}{c}4.1 \\
(15- \\
44)\end{array}$ \\
\hline
\end{tabular}


Table 2. Comparative evaluation of differences in extrusion effect of various incubation media.

\begin{tabular}{|c|c|c|c|c|c|c|}
\hline & $\begin{array}{l}\mathrm{NaCl} \\
0.9 \%\end{array}$ & $\begin{array}{c}\text { Digestion } \\
\text { solution }\end{array}$ & $\begin{array}{c}\text { Pepsin } \\
1 \%\end{array}$ & $\begin{array}{c}\mathrm{HCl} \\
24 \mathrm{mM}\end{array}$ & $\begin{array}{c}\mathrm{HCl} \\
48 \mathrm{mM}\end{array}$ & $\begin{array}{c}\mathrm{HCl} \\
72 \mathrm{mM}\end{array}$ \\
\hline Water & NS & * & * & * & * & * \\
\hline $\mathrm{NaCl}, 0.9 \%$ & & $*$ & $*$ & $*$ & $*$ & $*$ \\
\hline $\begin{array}{l}\text { Digestion } \\
\text { solution }\end{array}$ & & & $*$ & $*$ & NS & $*$ \\
\hline Pepsin, $1 \%$ & & & & $*$ & $*$ & $*$ \\
\hline $24 \mathrm{mM} \mathrm{HCl}$ & & & & & $*$ & $*$ \\
\hline $48 \mathrm{mM} \mathrm{HCl}$ & & & & & & NS \\
\hline
\end{tabular}

*: $\mathrm{p}<0.01, \mathrm{NS}$ : no significant difference

\section{Figure legends:}

Fig. 1.

a. Transverse section of Baltic cod liver tissue infected with a third stage larva of $C$. osculatum. Van Giesson staining showing pink reaction for collagen. CC: collagen containing cell, FI: Fibroblast-like cell, Ma: Macrophage like cell, AC: amorphous layer of collagen positive material. Scale bar: $100 \mu \mathrm{m}$

b. Haematoxylin and Alizarin Red staining of C. osculatum third stage larva in cod liver tissue. OE: oesophagus, GL: gland, Mu: subcuticular muscles, Ca: Alizarin stained Caencrustations. Scale bar: $100 \mu \mathrm{m}$ 


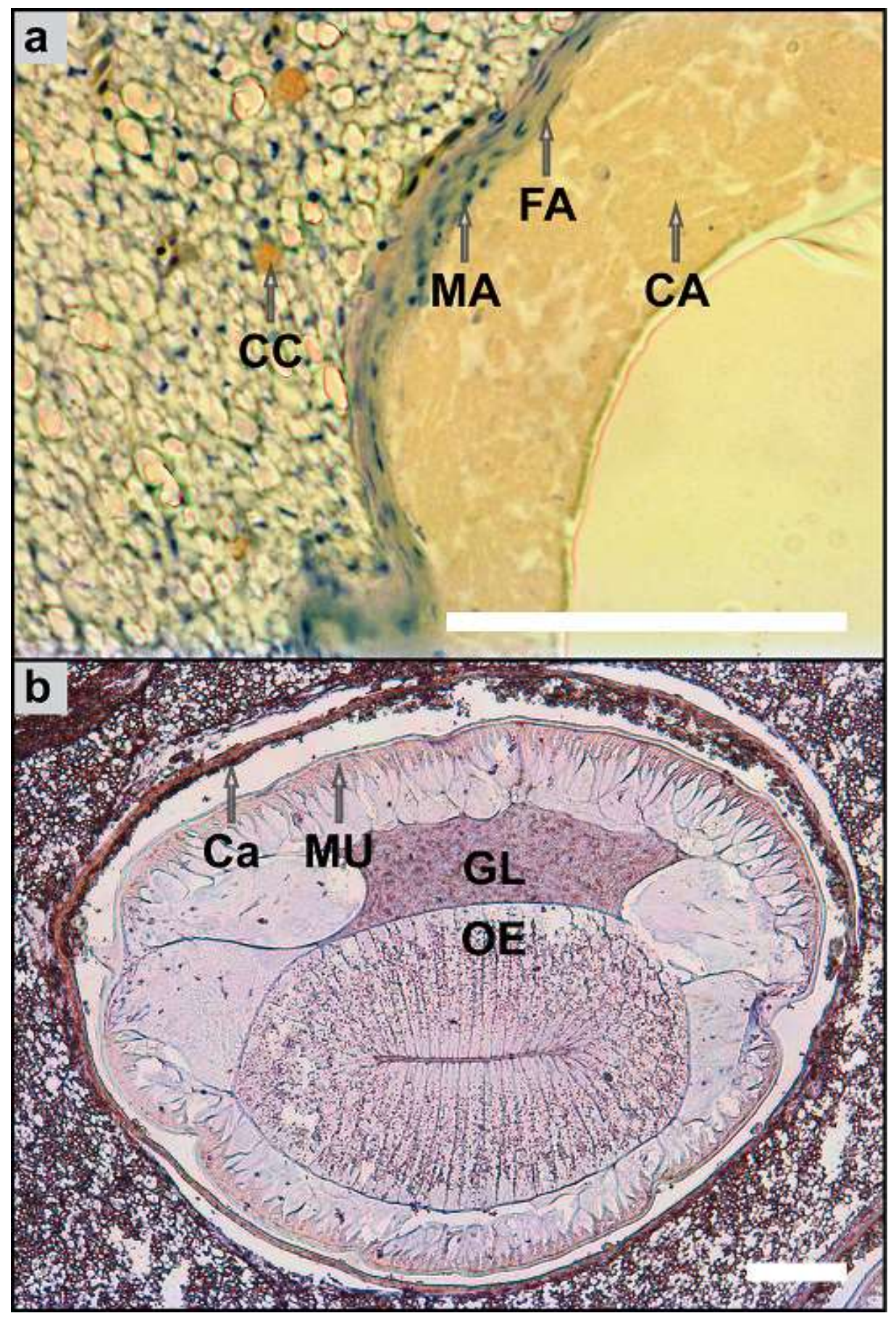


Fig. 2. Escape rates (percentage of total worm population escaped at each time point) of $C$. osculatum third stage larvae from Baltic cod liver tissue exposed to various media at $37{ }^{\circ} \mathrm{C}$

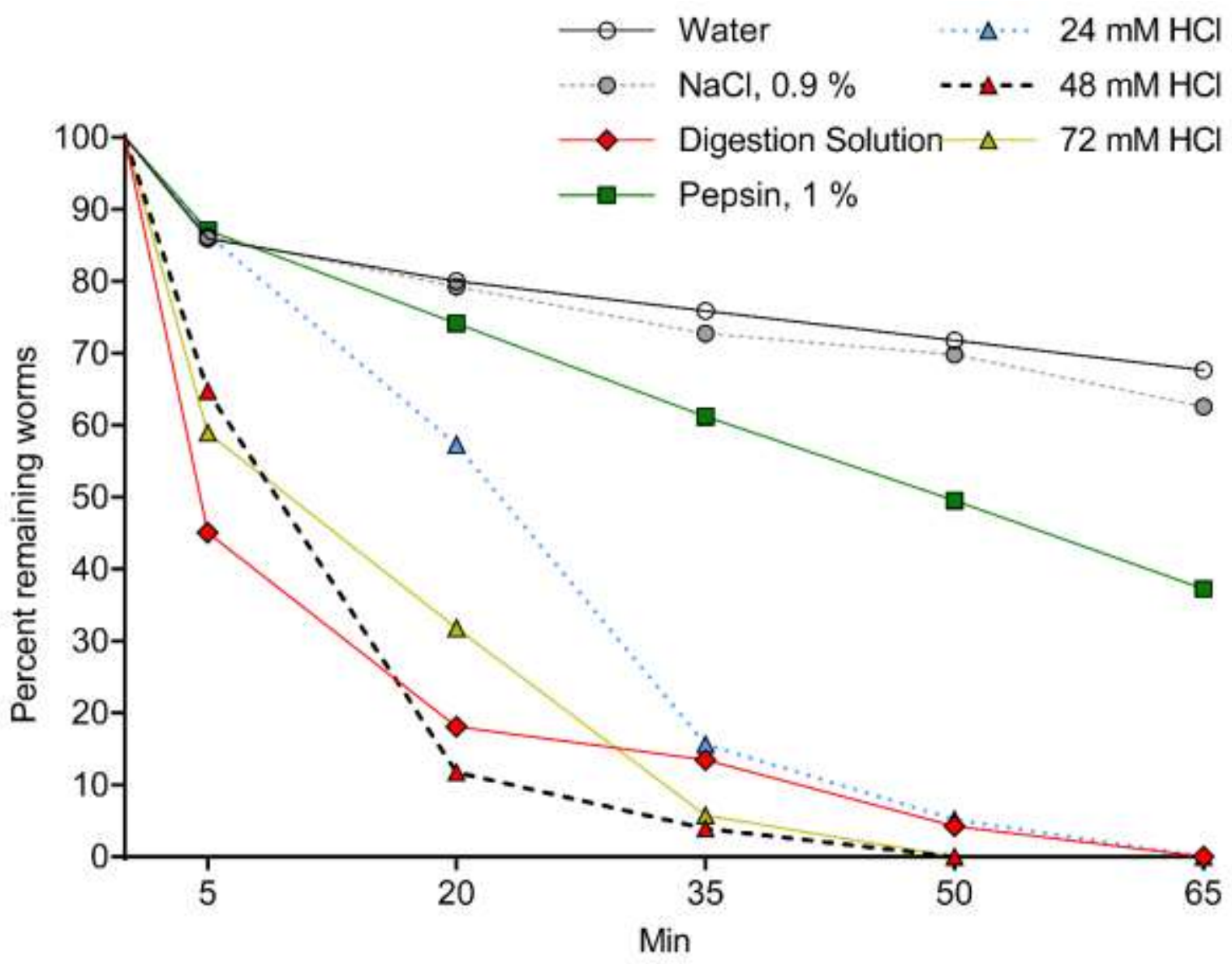

